\title{
The Effect of Cooperative Learning Model on Student Team Achievement Division (STAD) Type and Reading Habits of Exposition Text Writing Skills
}

\author{
Anisa Rusyda, Syahrul Ramadhan, Novia Juita \\ Indonesian Language and Literature Education \\ Universitas Negeri Padang \\ Email: anisarusyda@gmail.com
}

\begin{abstract}
This study was an experimental research which aimed at identifying the effect of implementation of Student Team Achievement Division (STAD) and reading habits of exposition text writing skills. This research is using quantitative method with a $2 x 2$ factorial experimental design. The study population was tenth-grade students at SMA Negeri 6 Padang. Data were collected through questionnaires and writing-skill tests towards text exposition. Based on the research, the cooperative learning model for STAD shows better results in enhancing the writing skills than the ones who were taught with conventional learning model.
\end{abstract}

Keywords-influence; STAD; conventional learning model, exposition

\section{INTRODUCTION}

Writing is one of the language skills. Writing skills are necessary to be mastered by students in learning process at schools, especially in learning Indonesian language and literature at high schools/MA. Writing is an activity to express thoughts, ideas or opinions, ideas and feelings (Suhaimi, 2016, p. 24). Writing is also an activity that is productive and expressive (Fitriyani, 2015, p. 130). The writing activity becomes an inseparable part of the whole learning process experienced by students in the school. Capability of writing does not come suddenly, but it needs to be trained continuously (Satini, 2016, p. 165).

This study discusses the teaching of writing text exposition. The exposition can be also called exposure, which is one form of paragraphs trying to explain, describe or analyze the main ideas that can expand knowledge and perceptions. Through the exposition text, students can peel and explain an idea or information to others (the Goddess, 2016, p. 2); (Samsudin, 2012, p. 3).

Based on initial observations and informal interviews towards Indonesian language teachers, Rosdawati, S. Pd, and tenth-grade students of Padang State High School 6 (further called as SMA 6 Padang), there are some instructional texts that a rose in the exposition. First, students still have not been able to write the text of exposition in accordance with the structure and rules that are required in Curriculum 2013. Students tend to use one or two texts of structure exposition, such as opinion statements (thesis), the arguments, and restatements. Second, the lack of students' vocabularies. Knowledge of the vocabularies is absolutely needed by every user of language, in addition to be a medium of ideas, to facilitate the flow of necessary information through oral and written communication. However, students are still limited in learning vocabularies, it is evident from the lack of information submitted by the students through their writing skills. Third, the lack of understanding of students' learning materials. Students are still difficult to understand the concept of the exposition text. This is because students do not have enough reading materials to write the text of the exposition. In addition, students do not follow the learning process seriously, so when they were assigned to write the text of exposition, the students did not produce good writing. Fourth, students do not understand the text properly in terms of linguistic elements, such as the use of effective sentences, diction selection, and the Legalized Prevailing Indonesian Spelling (hereinafter abbreviated to EBI). Fifth, students familiarize themselves lacking in reading. The reading habit of students is very influential on the text exposition writing skills. Students who have the good habit of reading the text exposition can normally produce good results. Sixth, the selection of the learning model used by the teachers still do not vary. Learning activities require learning models that can improve students' motivation to learn. However, teachers often use oration methods, so that students become passive in learning.

Based on that, the tenth-grade students of SMA 6 Padang still have difficulties writing text exposition. To help students writing text exposition, there is a need for learning model. Samsudin $(2012$, p. 2) states that teachers are the main actors to successful learning in practices. The ability of teachers to plan and choose the approach and the learning model of writing skills in accordance with the text and context becomes a necessity. Teachers should choose the model of learning that can involve all students to be active, making it easier for students to understand the material being taught. 
One model of learning that can be used is a cooperative learning model. Cooperative learning is a group learning activity organized by one principle, which must learn more deeply among learning groups in which each learner is responsible for his own learning and for enhancing the abilities of other members (Tanjung, Syahrul and Thahar, 2013 ) One of the cooperative learning models that can be done is the Student Team Achievement Divisions type cooperative model which will then be shortened to STAD.

The characteristics of STAD proposed by Slavin in Firdaus (2017) are: 1) the team usually consists of four people who are combined based on gender, ability and different ethnicities; 2) teachers present learning material and learners in their groups to ensure that all members have achieved the learning objectives; 3) students get quizzes related to the learning material at that time; 4) the assessment is averaged for each team and compared to the previous score; 5) teams that achieve certain criteria are awarded.

The selection of STAD model has been done by some previous researchers Tatalia, Syahrul, Ermanto (2015. p. 44); Widiarto, (2017, P. 88); Sunilawati, Dantes, Candiasa, (2013). Based on thosere searchers, the result shows that, in general, students who were taught using cooperative learning model STAD are better than students taught by conventional learning models.

Based on this, the cooperative model STAD is able to make learning more active because the most important thing in this model is the trigger to encourage each other and help each other to master the skills taught by the teacher. If students want to group a prize, they must help their friends in the study subjects. They should encourage their friends to be the best group, showing the norms that learning is important, worthwhile and enjoyable.

Based on the description, the research objectives are the following. First, describe the writing skills students who are taught exposition text using STAD type of cooperative learning model towards students taught using conventional models to tenth-grade students of SMA Negeri 6 Padang. Second, describe the exposition text writing skills' students who have a high reading habits using cooperative learning model type STAD to students who have a high reading habits taught using a conventional model to tenth-grade students of SMA Negeri 6 Padang. Third, describing the interaction between cooperative learning model STAD and reading habits of the exposition text writing skills tenth-grade students of SMA Negeri 6 Padang.

\section{METHOD}

The procedures in research data processing was performed using the figures. Figures in this study is the score and the value of reading habits questionnaires and scores and grades of text writing skills tests exposition tenth-grade students of SMA 6 Padang. Thus, it can be said that this study uses a quantitative approach.

The method used in this research is a quasi-experimental method. Quasy research experiment, the research aims to obtain information based on treatment to a trial unit within the design limits specified in the experimental class in order to obtain the data that describes the expected results. According to Sugiyono (2012), the experimental quasy can be used as follows (external variables cannot be changed which affect the implementation of the experiment).

This study aims at describing the effect of the application of cooperative learning model STAD and reading habits of the exposition text writing skills to tenth-grade students of SMA Negeri 6 Padang. Implementation of the study includes the presentation of learning by using cooperative learning model STAD and presentation of conventional teaching methods. The design was a $2 \times 2$ factorial. According to Suwanda (2011) factorial design is the most efficient design to investigate the effects of two or more factors. In this study will be seen the effect of using the STAD type cooperative model and reading habits on the ability to write student exposition text.

The study population is all of the tenth-grade students of SMA Negeri Padang registered 6 2017/2018 as the population in this study. The tenth-grade students of SMA Negeri 6 Padang scattered in nine classes with the number of 303 people. Sampling in this study was conducted by random sampling technique. Determining the experimental class and control class was using random sampling technique. As such, the tenth-grade students of IPA 2 as an experimental class and the tenth-grade students of IPA 4 as the control class. Based on class normality and homogeneity test samples, the results are normally distributed both this class and homogeneous.

The study consists of three variables. First, the independent variable is cooperative learning model STAD. Second, the dependent variable is a text writing skills exposition. Third, the moderator variable is the habit of reading. The data was used in this study. First, score the results of the questionnaire filling the habit of reading. Second, score the test result students' writing skills by using a text exposition cooperative learning model STAD and the conventional model. Third, score the writing skills test result that uses cooperative learning model STAD. Fourth, score writing skills test result exposition text that uses the conventional model.

The instrument used to collect the data of this study consists of two instruments, namely sheet questionnaires and test performance. Sheet questionnaires were used to determine the habit of reading while the performance of the test was used to measure students' skills in writing text exposition. The questionnaires consist of 50 statements, having obtained a valid result consists of 47 statements and the invalid one consists of three statements. Data tables are valid if $\mathrm{r}<\mathrm{r}$ count. Third, after obtaining validity, then determine whether the data is reliable or not. Based on the research that 
has been done, the question naires declared a reliable result because the table $r<$ r11 $1.034174<0.6$. Fourth, the valid statement is distributed to the experimental class and control class.

The exposition-text-writing test on this research is a form of performance. The steps in preparing the text written test instrument exposition, as follows. First, the manufacture of lattice based on indicators. Second, composing tasks or order in accordance with the test indicators. Third, doing a rational analysis to look at the suitability of items with the aspects measured. Fourth, make an assessment for rubric exposition text writing skills. Fifth, make Learning Implementation Plan (RPP) and test instruments exposition text writing skills. Sixth, Learning Implementation Plan (RPP) and writing skills test instruments which have validated beforehand and consulted to a validator professor, Dr. Abdurahman, M.Pd.

\section{FINDING AND DISCUSSION}

In this section, we will describe two things about the result of the writing skills of exposition text control class and experimental class, as follows. First, exposition text writing skills of students taught by cooperative learning model STAD and conventional learning models. Second, exposition text writing skills of students that have a high reading habits taught by cooperative learning model STAD and conventional learning models. Third, there is no interaction between cooperative learning model STAD and the habit of reading the text writing skills exposition.

\section{Students Exposition Text Writing Skills in Learning when using STAD Cooperative Learning Model and Conventional Models}

The first hypothesis testing results revealed that overall, the ability to write text exposition taught using STAD cooperative model is better than the ability to write text exposition using conventional methods. It is seen from testing hypotheses suggesting that the real level of $0.05 \mathrm{t}_{\text {hitung }}=1,87>\mathrm{t}$ tabel $=1,65$.

STAD cooperative learning model of the student in the form of a heterogeneous group was seen in many aspects in terms of academic ability. A group or team which has formed aims at facilitating students to discuss what they found during the learning process. This is in accordance with the opinion from Widyantini (2008). "Cooperative learning STAD type of cooperative learning is the simplest and can be used to provide insight into the concept of a difficult material to students in teaching the material" (Ikhsanudin, 2014).

The first component of STAD cooperative learning is a class presentation. Class presentations are made by teachers with the intention of introducing the material to write text exposition, open up the minds of students about the text exposition, exposition text structure. Furthermore, the formation of a heterogeneous team with the aim that all members can study well and prepare its members to understand the teaching of writing text with a good exposition. Problems faced in the group are discussed together so that students can dig in the group. In groups, students can ask to a friend group, intergroup friends, even teachers. In groups, students define concepts, which they got from the presentation and expressed by teachers.

The next component is the quiz, the quiz exposition learning to write the text can be interpreted as a test given to the group to work individually. The quiz was given once the study was completed. Students in the group can talk to each other to over come constraints faced, even they are allowed to compare answers of the given asks. Any questions, comments, and answers raised by members of the group will be given points by the teacher. It can encourage students to be encouraged and motivated to generate interest in learning. The points collected by each group will be calculated and the group that has the highest point got prizes or awards.

The given tests are to test the performance, a test to write text exposition was conducted in the experimental class and control class. The given test to the two classes is the same, there is no difference whatsoever. This test is done to see the effect of the application of cooperative learning model STAD on the ability to write exposition text class X SMA Negeri 6 Padang.

The learning process in the experimental class more lively and active than the learning process in the control class. In the experimental class, students in groups are actively discussing proposed by the teacher. In addition, students are also motivated to express their opinions, questions and answers to get points group.

Unlike the cooperative learning model, conventional learning methods of students as a learning object that acts as a passive recipient object. Students only receive information provided by a source of learning or teacher. In general, conventional learning model implemented methods lectures, discussion and assignments. This is in accordance with the opinion. Sanjaya (2006) states that the conventional learning students are placed as an object that acts as a passive recipient of information. So, in general, the delivery of lessons using methods lectures, discussion and assignments. Teachers always dominate the learning activities, while students act as learning objects that must absorb all of the information from the teacher. There is no opportunity for students to participate to the learning. Learning is centered on the teacher or teacher-centered and lecturing is the main selection of teachers in presenting the material.

The condition is seen as the research progresses, the control class which was taught by applying conventional teaching methods tends to be passive. Students were listening to the explanation of the teacher, noted learning materials, and answered questions raised by the teacher. Students are not motivated to ask themselves let alone express 
concepts related to learning materials. If the material presented by teachers have started being boring, students are more inclined to joke with his intrusive way. Lastly, students work on the assignment of teachers.

The test results of students' writing ability in the control class that students are less able to write exposition text. This is evident from the average obtained by the control class is 77.90 . This figure shows that the average ability students in the control class to write exposition text remains assigned to the school, grade 79. Students are less able to write a text control with good exposition, it is seen from the writings of students who do not meet the exposition text structure, errors the use of capital letters and sentences are not effective.

Based on these descriptions, it can be concluded that the results of data analysis showed that the cooperative learning model STAD influence and positive impact on the students' ability to write text exposition. The results of the test performance of the experimental class where students are taught using a model STAD cooperative higher than the results of the test performance of students taught using the method.

\section{Exposition Text Writing Skills of Students Who Have High Reading Habits Using STAD Cooperative Learning Model and Conventional Models}

Hypothesis testing both show the results of which states that, in general, the ability to write text exposition of the students who have the habit of reading in class experiment taught using cooperative STAD model better than students who write news text with having the habit of reading in class control taught with conventional teaching methods. This can be seen from the calculation of the hypothesis test shows $t_{\text {hitung }}=3,52>\mathrm{t}$ tabel $=1,75$ on a real level of 0.05 and $\mathrm{df}$ 16. The calculation results indicate that acceptable since $\mathrm{H}_{1} \mathrm{t}_{\text {hitung }}>\mathrm{t}$ tabel.

STAD cooperative learning model can improve the writing ability of students who having high reading habit. This is in accordance with the principles from Asma (2012), which states "Cooperative learning contains five principles, namely the principles of active learning, learn to cooperate, learn patriotic, reactive teaching and fun learning". In cooperative learning, students are required to be active in the learning process, active in groups, discover and discuss, answer questions, find the concept.

Further reading habits also the ability to write text exposition. Students will be able to write texts with good exposition. In this case the habit of reading will help students discover, reveal, and realize that they are abstract ideas in writing and compile them into a good text arrangement.

Based on the above, it can be concluded that the results of the ability test to write exposition text of students who have a high reading habits are taught using cooperative models better than students who have a high reading habits taught using conventional methods.

\section{Interaction between Reading Habits and Model Cooperative Learning STAD in Influencing Exposition Text Writing Skills}

A count result from two-way ANAVA for the fourth hypothesis testing showed that there is no interaction between cooperative learning model STAD type with the reading habits of the ability to write exposition text, meaning that the main influence factors of STAD cooperative learning and reading habits of each run independently in affecting the ability to write exposition text. In other words, there is no influence of the interaction of cooperative learning model STAD categories and reading habits of the ability to write text exposition. Many other factors may be supporting the ability to write exposition text such as talent, intelligence, and others.

The absence of interaction between STAD cooperative learning model and reading habits occurred on the second level reading habits, both of which have a high reading habits, or who have low reading habits. The absence of these interactions means that each of the factors of the model type STAD cooperative learning and reading habits do not depend on each other in affecting the ability to write a news text for experiment and control class. However, the model STAD cooperative is more effectively applied to the second level of the reading habit.

\section{CONCLUSION}

Based on the results of this study, it can be concluded that the STAD type cooperative model influences the learning outcomes of writing the exposition of students. First, the results of students' expositional writing ability writing skills using the STAD type cooperative model with an average of $x^{-}=82.02$ are higher than the average yield by using conventional methods with an average of $\mathrm{x}^{-}=77.90$. This is because the reason given by using the STAD model has advantages such as, the students are better able to float ideas, ideas, and knowledge to help at stages in the STAD model. Second, the result of the ability to write expository text students who have high reading habits that use a higher STAD model that has a habit of reading by using conventional methods. Third, there is no interaction between the STAD model with the habit of making the exposition text for tenth grade students of SMA Negeri 6 Padang. This means that without using reading habits, the STAD model still affects the learning outcomes of writing the exposition text of the students. Furthermore, students who have high or low reading ability can be taught using the STAD model. 


\section{References}

Asma, N. (2012). Model pembelajaran kooperatif. Padang: UNP Press.

Dewi, A, S, S, P. (2016). Kemampuan menulis paragraf eksposisi siswa kelas X SMA Negeri 12 Konawe Selatan. Jurnal Humanika, 16(1).1-19.

Firdaus. (2017). Penerapan model pembelajaran model cooperative learning tipe STAD untuk meningkatkan kemampuan membaca pemahaman bahasa Inggris. Jurnal Penelitian Pendidikan, 17(1). 20-27.

Fitriyani, D. (2015). Penguasaan kalimat efektif dan penguasaan diksi dengan kemampuan menulis eksposisi pada siswa SMP. Jurnal Pesona, 1(2) 129-139.

Ikhsanudin. (2014). Pengaruh penggunaan pembelajaran kooperatif tipe STAD berbantuan wingeom terhadap kemampuan pemecahan masalah geometri siswa SMA. Jurnal Pendidikan Matematika Univ Muhammadiah Metro (Aksioma), 3(1), 40-49.

Samsudin, A. (2013). Peningkatan kemampuan menulis eksposisi berita dan eksposisi ilustrasi siswa kelas V melalui model pembelajaran kooperatif terpadu membaca dan menulis. Jurnal Penelitian Pendidikan, 13(2), 11.

Sanjaya, W. (2006). Strategi pembelajaran berorientasi standar proses pendidikan. Jakarta: Perdanan Media.

Satini, R. (2016). Kemampuan menulis karangan eksposisi dengan menggunakan teknik mind map siswa kelas X SMA negeri 14 Padang. (online). Jurnal Gramatika, 2(2), 164-179.

Sugiyono. (2012). Metode penelitian pendidikan pendekatan kuantitatif, kualitatif, dan R\&D. Bandung: Alfabeta.

Suhaimi. (2016). Teaching writing skill on recount text based on brainstroming in the classroom. (online) Jurnal Tadib, Vol. 19, No. 1 (Juni 2016).

Sunilawati, Dantes, Candiasa. (2013). Pengaruh model pembelajaran kooperatif tipe STAD terhadap hasil belajar matematika ditinjau dari kemampuan numerik siswa kelas IV SD. E-Journal Program Pascasarjana Universitas Pendidikan Ganesha, 1(3),1- 9.

Suwanda. (2011). Desain eksperimen untuk penelitian Ilmiah. Bandung: Alfabeta.

Tanjung, Syahrul, Thahar. (2013). Pengaruh model pembelajaran kooperatif tipe think pair share dan tipe two stay two stray terhadap hasil belajar bahasa Indonesia siswa kelas X SMA Negeri 1 Angkola Barat Kabupaten Tapanuli Selatan.

Tatalia, Syahrul, Ermanto. (2015). Pengaruh model pembelajaran kooperatif tipe STAD berbantuan pemetaan pikiran (mind mapping) dengan mempertimbangkan motivasi belajar terhadap kemampuan menulis teks berita siswa kelas VIII SMP Negeri 1 Panti. Jurnal bahasa, Sastra, dan Pembelajaran, 3(1), 36-45.

Widiarto, S. (2017). Pengaruh metode teams achievement division (STAD) dan pemahaman struktur kalimat terhadap keterampilan menulis narasi. Lectura; Jurnal Pendidikan, 8(1), 82-89. 